\title{
EMPLOYMENT CONDITION, THE EFFECTS OF HUSBAND'S OCCUPATION, AND EDUCATION ON PARTICIPATION OF MARRIED WOMEN IN THE INDONESIAN LABOR MARKET
}

\author{
Muhammad Rizqon Agusta ${ }^{1}$, Diny Ghuzini \\ ${ }^{1}$ Badan Pusat Statistik, rizqon.agusta@bps.go.id; \\ ${ }^{2}$ Fakultas Ekonomika dan Bisnis, Universitas Gadjah Mada, dinyghuzini@ugm.ac.id.
}

\begin{abstract}
A previous study has shown that households with both the head and the spouse joining the labor force tend to exit from poverty. In Indonesia, women that actively participated in labor market were relatively small, only around 50\% in 2017. Meanwhile, most of the women in Indonesia were married in 2017. A husband was one of the factors affecting their wife's decision to participate in labor market. This study investigates married women's employment conditions and the effects of husband's occupation and education on their labor market participation. The research sample consists of women aged 15-year-old and above, married, and living with their husband. We found that the higher the husband's education, the lower married women's probability of participating in the labor market. Husbands with an informal occupation increased married women's probability to be in the labor force.
\end{abstract}

Keywords: female labor participation, husband's occupation, husband's education, married women, informal worker

JEL Classification: E2, J08, J21, J24, J46

\section{Abstrak}

Studi terdahulu menyimpulkan bahwa rumah tangga yang kepala rumah tangga dan pasangannya bekerja cenderung terlepas dari kemiskinan. Di Indonesia, perempuan yang berpartisipasi aktif dalam pasar tenaga kerja relatif rendah, hanya sekitar 50\% pada tahun 2017. Di sisi lain sebagian besar perempuan Indonesia berstatus kawin pada periode yang sama. Suami menjadi salah satu faktor yang memengaruhi keputusan perempuan kawin untuk berpartisipasi di pasar tenaga kerja. Tujuan dari studi ini adalah untuk mengetahui kondisi ketenagakerjaan perempuan kawin dan untuk mengetahui pengaruh pekerjaan dan pendidikan suami terhadap partisipasi perempuan kawin di pasar tenaga kerja. Sampel penelitian terdiri dari perempuan yang berumur 15 tahun atau lebih, berstatus kawin, dan tinggal dalam satu rumah dengan suaminya. Hasilnya menunjukkan bahwa semakin tinggi pendidikan suami, semakin rendah peluang perempuan kawin untuk berpartisipasi di pasar tenaga kerja. Suami yang berstatus sebagai pekerja informal meningkatkan peluang perempuan kawin untuk bekerja.

Kata kunci: Partisipasi kerja perempuan, pekerjaan suami, pendidikan suami, perempuan kawin, pekerja informal

Klasifikasi JEL: E2, J08, J21, J24, J46 


\section{INTRODUCTION}

Women's participation in the labor market in Indonesia is relatively low, only about $50 \%$ of the total working-age women. Meanwhile, men's participation rate is more than $80 \%$ of the total working-age men. The BPS data shows that from the total women aged more than ten-year-old in 2017 , most of them or $60 \%$ were married. The other categories are single women and divorced/ widowed with $27 \%$ and $13 \%$ respectively. Various factors influence the women's participation rate, leading to the lower participation rate of women in the labor market.

Married women play an important role as a wife and mother managing their households as well as raising their children, according to Beechey (1986) in Suhapti (1995). The role may explain why some married women chose not to work. However, it must be noted that married women who go to work are vital factors that may solve poverty in their household (Addabbo, 2000). The husband becomes one of the factors affecting women or wife participation in labor market. As the household head, the husband is given authorities to make a decision in the family (Tzannatos, 1999). İlkkaracan (2012) and Noerdin et al. (2006) argue that disparity between men and women in participating in the labor market is due to the need for married women to obtain their husband's permission when they want to work.

Research on the effects of a husband's occupation and education on married women's participation in the labor market had been widely conducted in many countries. These research focused on husband's occupation, such as, blue-collar or white-collar worker (Engle, 1985; Bredtmann et al., 2018), employed and unemployed (Del Boca et al., 2000; Karaoglan \& Okten, 2012; Bibi \& Afzal, 2012; İlkkaracan, 2012; Klasen \& Pieters, 2015). Research on this topic in Indonesia is limited; one of the research is written by Rantau \& Zain (2013). They examine husband's employment status, employed or unemployed, affects the married women's participation in the labor force in Jawa Timur. This study is different from the previous ones in that we use formal or informal worker as the type of husband's occupation. About half of the total number of Indonesian people worked in informal sectors in 2017. Those who work in the informal sector reveal that most of them were unprotected, insecure, and vulnerable since they did not benefit from the government and private companies (ILO, 2002). Informal workers frequently received a low salary, making them unable to pay for their family's education and health facilities. In addition to that, they also might not be able to save for anticipating any emergencies (Bertulfo, 2011). Another characteristic of the informal sector is that the workers' productivity and income tended to be lower than formal workers (Todaro \& Smith, 2012). The study's objective is to investigate the employment condition of married women in Indonesia and the effects of husband's occupation and education on the participation of married women in the Indonesian labor market.

\section{LITERATURE REVIEW}

A person's decision to participate in the labor market is influenced by various factors. This also applies to married women. Husbands are one of the factors that influence married women's decision to work in Indonesia because the husband, as the head of the family, strongly influences decisions made in the family. The education that the husband receives will affect the insights of his decisions. This education can make the husband get a decent job with a high income. The husband's job can also influence a married woman's decision to work. Apart from husband's education and occupation, married women's decision to participate in the labor market can also be influenced by other factors, such as education, age and place of residence of married women and the number of children under five-year-old.

Individual participation in the labor market is determined by the decision in time use. Becker (1965), in his theory on time allocation, asserts that individuals allocate their time for working or other (the leisure) activities. Their decision to participate in labor force is a choice on how much leisure time they give up for work. Since the leisure time is limited, the more time they use to work the less opportunity to spare for leisure time due to the limitation created. However, the working time will be converted into a salary used for consumption. In other words, the supply of labor is the other side of demand for leisure. Borjas (2012) proposes the 
same argument that working decision is a decision of how to allocate the available time to work and for leisure to gain maximum utility. However, individuals do not only allocate their time to work and do leisure activities, but also perform any household activities such as cooking, washing, or playing with children. Such activities are called household production (Ehrenberg \& Smith, 2012). Household production is often equalized to other works, as the salary earned by working may be used to pay ones to substitute others for doing their household production.

Ehrenberg \& Smith (2017) say that in general, demand for goods constitutes a function given by three factors, i.e. opportunity cost of the service/ goods, welfare level, and preference. When leisure is regarded as goods, then opportunity cost or the price of one-hour leisure of an individual can be measured based on the salary earned in an hour. Therefore, the higher the salary, the more expensive the cost of one-hour leisure. Individual welfare level may be observed by the amount of deposit, investment, or property ownership (non-labor income). Welfare level will influence the minimum salary earned to give up their leisure time. A good combination of working and leisure time is determined by individuals' preferences and is different among people. One decides to consume goods or allocate their time to work, and leisure is to obtain maximum utility.

Ehrenberg \& Smith (2017) state that married ones will decide together to allocate their time and agree over who will do some particular household chores. Therefore, interactional relationship in a household may influence someone's working decision. Eckstein \& Lifshitz (2015) divides household based on husband-wife interaction into three, namely classic household, modern household, and cooperative household. In the first household, classic household, the husband makes all decisions and determines whether or not his wife goes to work. When one partner, say the husband earns more than the wife, then the later (wife) usually tends not to work, since their earnings are substitute. Commonly, the wife is the one that chooses to stay at home; however, she will look for a job when the husband's salary is inadequate. Unlike the first household, the second and the last households, both husband and wife play a balanced role and own the same authorities to make their own decisions. The difference between the second and third household lies in the fact that a cooperative household decision is an efficient one.

As the head of a household, husbands play an important role in major household decisions, including their wive's decision to join the labor force (Tzannatos, 1999). Furthermore, husband's education may affect whether they permit their wives to work. Bibi \& Afzal (2012) found evidence that husband education is positively related to wife's participation in Pakistan's labor market. A study by Del Boca et al. (2000) concluded that a husband's education is positively related to married women's probability of working. Husband with better education is also more likely to land more decent jobs with a higher salary. Rantau \& Zain (2013) found that husband's education affects married women's decision to work in Jawa Timur. Husband's education negatively affects women's participation to work in the US (Duncan et al., 1993), India (Klasen \& Pieters, 2013; Unni, 1994), Jepang (Mano \& Yamamura, 2011), and Turkey (İlkkaracan, 2012; Karaoglan \& Okten, 2012). The relationship is negative because husband with high education tends to have higher income and therefore increase the non-labor income of married women.

Beside husbands' education, married women's decision to participate in the labor market is also influenced by their husbands' occupation. Husbands who are self-employed will increase the chances of married women to work (Engle, 1985). Khan \& Khan (2009) explain that women's participation is commonly determined by a financial vulnerability in their household that greatly depends on their husbands' occupational status. Bredtmann et al. (2018) found that the more stable husband's jobs, measured by length of jobs, the less likely the wife will enter the labor force or switch from part-time to full-time workers. Higher husbands' salary also lower married women's opportunity to work in the US (Long \& Jones, 1980), Italy (Del Boca et al., 2000), Mexico (Anderson \& Dimon, 1998), Japan (Sasaki, 2002), and India (Klasen \& Pieters, 2013). 
Hart (1973) began to introduce the informal sector term after conducting research in Accra Ghana. He grouped profitable activities conducted by the poor living in the city into two, formal and informal activities. The difference was based on the income source, whether the income comes from salary income or personal income. An informal sector may also be defined as an unorganized, unregulated, or unregistered sector (Todaro \& Smith, 2012). Informal sector accommodates workers without specific requirements on education level and skills, making it easier for workers to enter the sector (Muzakir, 2010). Urban residents go to the sector to help them survive because job opportunities provided by formal sector is insufficient to accommodate all of the people migrating to urban areas. Todaro $\&$ Smith (2012) argue that around 30\% to $70 \%$ of urban communities living in most developing countries work in informal sectors. The sector plays a role as a national economic stabilizer when the economy is in crisis and still in the recovery phase. As an illustration, during the monetary crisis in 1997, the decreased economic activities resulted in massive employment termination, which increased unemployment level. At that time, the informal sector absorbed the terminated workers and prevented Indonesia's economy from deteriorating (Pitoyo, 2007).

Activities in informal sector arise and develop without any appropriate capital, skill, and business pattern as the response of powerless conditions (Yustika, 2000). It weakens the informal sector's chance to compete in an either domestic or export market and hence becomes a serious obstacle for both the sector's development and growth. The sector is also called the shadow economy. Shadow economy activities are badly connoted, as being able to avoid tax, break the rule, do not meet the employment standard, and do not have any permission, the potential for making the country suffer from loss (Frey \& Schneider, 2000). Additionally, vulnerability is also one of the informal sector characteristics (Bertulfo, 2011). Labors in informal sectors are not protected by health and safety legislation. They do not receive overtime payment, minimum wage, paid vacation, sick leave, health insurance, unemployment insurance, maternity benefit, pension benefit, and nursery facility are not provided for the workers. Informal workers can hardly get a loan to pay their housing and education, and they are also vulnerable to exploitation due to their unwritten work contract. Most informal workers come with low salary and unable to afford their children's education and health service for themselves and their families. Besides, they have less capacity to save their money for any future emergency. Todaro \& Smith (2012) also argue that the lack of formal education for informal workers leads to a shortage of skills and capital. It then reduces their productivity and income, lower than that of the formal sector workers.

BPS (2017) used three approaches or proxies to identify formal and informal activities in Indonesia. First, formal and informal workers referring to their primary occupational status. The second is based on cross-tabulation between the main occupational status and the main type of work. The third adopts the concept of formal and informal work which was initiated through the $17^{\text {th }}$ International Conference of Labor Statistics (ICLS). The study uses the first proxy, workers with the main occupational status: doing business assisted by permanent/paid labor or labor/workers/employees are assigned as formal workers; while another occupational status that includes private efforts, doing business assisted by temporary/paid worker, independent worker, family/unpaid worker are assigned as informal workers.

In addition to husband's education and occupation, which is the main variable of interest, married women's decision to work is also influenced by other factors that include their education level, age, place of residence, and the number of young children. If education is considered an investment, women's opportunities to work will increase. Other individual characteristics, age, are also influence the work decisions of married women (Bredtmann et al., 2018; Hafeez \& Ahmad, 2002; Karaoglan \& Okten, 2012; Ribar, 1992; Unni, 1994). Apart from individual characteristics, family and place of residence factors also influence a person's work decisions. Children's existence is one of the family factors considered by married women in deciding to work or not work (Bredtmann et 
al., 2018; Engle, 1985; Maloney, 1987; Mano \& Yamamura, 2011; Ribar, 1992; Sasaki, 2002). A labor market that is not a prospect for women will negatively affect women's participation in the labor market (Long \& Jones, 1980). Hafeez $\&$ Ahmad (2002) stated that rural areas reduce the opportunities for educated women to work due to the unavailability of jobs for these women. Research conducted by Ribar (1992) also shows that living in a metropolitan area positively affects the opportunity for married women to work. Anggraeni's research (2015) in Melati (2018) found that the availability of work types in villages that are more flexible in working hours encourages women in rural areas to be more economically active than women in urban areas.

\section{RESEARCH METHOD}

Data used in the study were drawn from the raw data of Survei Sosial Ekonomi Nasional (SUSENAS) conducted by BPS in March 2017. SUSENAS is one of BPS surveys that is the main data source to capture the development of social and economic conditions in Indonesia. The SUSENAS data consists of various socioeconomic aspects such as food, clothing, shelter, education, health, security, and employment. This study focuses on the sample of women aged 15-year-old and above, married, and living with her husband $(237,881$ women). The information on their husbands' education and occupation status, were also collected.

The method used to examine the employment condition of married women was descriptive analysis. While probit regression is used to analyses the effect of husband's education and occupation on the participation of married women in labor market. Del Boca et al. (2000) used husband's education (years) and unemployment condition (unemployed/ employed) to analyses the employment decision of married women. Hafeez \& Ahmad (2002) also used education years of husband while Klasen \& Pieters (2015) used the household head's education level. Karaoglan \& Okten (2012) used husband's education level and employment condition (fired/ underemployed/employed). This study also used husbands' education (years) as in the previous study, what makes the difference is the use of the husband's occupation (formal/informal). Husband occupation reflects the economy level of married women, which is one of the reason to work. Formal workers tend to earn more than those of informal workers. This study does not include household expenditure as one of the control variables due to the possibility of reverse causality between household expenditure and women's probability of works where the expenditure might increase if the wife works. Based on that previous study, we construct this following model (equation 1) to analyse the effect of husband's education and occupation on the participation of married women in labor market (other control variables are included, which are age, age squared, location, and the number of children).

$$
\begin{aligned}
P\left(Y_{i}=1 \mid X\right)= & \beta_{0}+\beta_{1} \text { husband_school }_{i} \\
& +\beta_{2} \text { informal_husband }_{i} \\
& +\beta_{3} \text { school }_{i}+\beta_{4} \text { age }_{i} \\
& +\beta_{5} \text { age }_{i}^{2}+\beta_{6} \text { urban }_{i} \\
& +\beta_{7} \text { child }_{i}+\varepsilon_{i}
\end{aligned}
$$

where are the regression coefficients, $Y$ was the labor status of married women, $Y=1$ when the woman is in the labor force and $Y=0$ when the woman is not in the labor force, husband_school is the husband's years of education, informal husband is the husband's occupational status, it equal to one if the husband is an informal worker and zero if the husband is a formal worker, school is the years of education of the woman, age is the woman's age (in year), urban is the classification of woman's residence $(0=$ rural area, $1=$ urban area), and child is the number of children under five-year-old of the woman.

\section{RESULTS AND DISCUSSION}

\section{Employment Condition of Married Women in Indonesia}

The study found that in 2017 the percentage of married women that participated in the labor market was $56 \%$ and therefore the percentage of married women that did not participate in labor market was $44 \%$ (Figure 3). The proportion of married women not in the labor force was relatively high. Since the BPS data also shows that most Indonesian women are married (Figure 1), there is a concern to increase the married women 


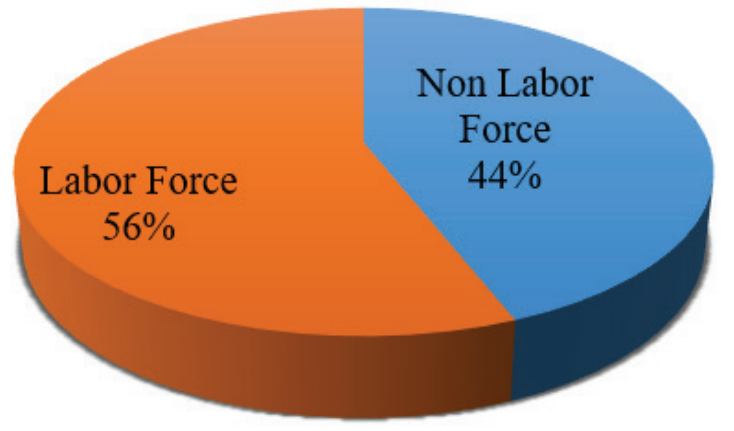

Figure 3. Percentage of Married Women According to Their Participation in Labor Market in 2017

Source: Authors' calculation from data are used in the regression analysis

to participate more in the labor market. Overall, the woman's labor force participation rate was $50.89 \%$ in the same year.

Table 2 indicates the summary statistics of the variables used in the study. The average years of education for married women participating in the labor market were 8.27 years. It is higher than that did not participate in the labor market (8.04 years). In contrast, the average of husband's years of education of the married women in the labor market is lower ( 8.45 years) than that of the second category ( 8.47 years). Table 2 also confirms that married women who did not participate in the labor market had more numbers of children under five-year-old, on average, than that participating.

Table 2. Summary Statistics of Married Women' Characteristics

\begin{tabular}{|c|c|c|c|c|c|}
\hline \multicolumn{2}{|l|}{ Characteristics } & \multirow{2}{*}{$\begin{array}{l}\text { Unit } \\
\text { (2) }\end{array}$} & \multirow{2}{*}{$\begin{array}{l}\text { Mean } \\
(3)\end{array}$} & \multirow{2}{*}{$\begin{array}{l}\text { Min } \\
(4)\end{array}$} & \multirow{2}{*}{$\begin{array}{l}\text { Max } \\
(5)\end{array}$} \\
\hline (1) & & & & & \\
\hline \multirow{3}{*}{$\begin{array}{l}\text { Husband's } \\
\text { education }\end{array}$} & $\begin{array}{l}\text { Labor } \\
\text { Force }\end{array}$ & Year & 8.45 & 0 & 22 \\
\hline & $\begin{array}{l}\text { Non } \\
\text { Labor } \\
\text { Force }\end{array}$ & Year & 8.47 & 0 & 22 \\
\hline & $\begin{array}{l}\text { Labor } \\
\text { Force }\end{array}$ & Year & 8.27 & 0 & 23 \\
\hline Education & $\begin{array}{l}\text { Non } \\
\text { Labor } \\
\text { Force }\end{array}$ & Year & 8.04 & 0 & 23 \\
\hline
\end{tabular}

\begin{tabular}{|c|c|c|c|c|c|}
\hline Characteristics & & Unit & Mean & Min & Max \\
\hline \multirow[b]{2}{*}{ Age } & $\begin{array}{l}\text { Labor } \\
\text { Force }\end{array}$ & Year & 41.19 & 15 & 94 \\
\hline & $\begin{array}{l}\text { Non } \\
\text { Labor } \\
\text { Force }\end{array}$ & Year & 38.89 & 15 & 95 \\
\hline \multirow{2}{*}{$\begin{array}{l}\text { Numbers of } \\
\text { children under } \\
\text { five-year-old }\end{array}$} & $\begin{array}{l}\text { Labor } \\
\text { Force }\end{array}$ & Person & 0.27 & 0 & 5 \\
\hline & $\begin{array}{l}\text { Non } \\
\text { Labor } \\
\text { Force }\end{array}$ & Person & 0.40 & 0 & 4 \\
\hline
\end{tabular}

Source: Authors' calculation from data are used in the regression analysis

Table 3 shows the percentage of married women in the sample based on their husband's occupation and residence. Most of their husbands were informal workers. For women in the labor force, the percentage of married women whose husbands worked as informal workers were $64.24 \%$ whereas those not in the labor force were $55.72 \%$. Table 3 also indicates that most married women lived in rural areas, either those that labor force $(61.58 \%)$ ) or those that non labor force $(57.07 \%)$.

Table 3. Married Women's Husband Occupation and Residence

\begin{tabular}{llll}
\hline Characteristics & $\begin{array}{l}\text { Labor } \\
\text { Force (\%) }\end{array}$ & $\begin{array}{l}\text { Non } \\
\text { Labor } \\
\text { Force (\%) }\end{array}$ \\
\hline (1) & $(2)$ & $(3)$ \\
\hline $\begin{array}{l}\text { Husband's } \\
\text { Occupation }\end{array}$ & Formal & 35.76 & 44.28 \\
& Informal & 64.24 & 55.72 \\
\hline \multirow{2}{*}{ Residence } & Rural & 61.58 & 57.07 \\
& Urban & 38.42 & 42.93 \\
\hline
\end{tabular}

Source: Authors' calculation from data are used in the regression analysis

Percentage of married women by the amount of per capita expenditure, husbands' occupation, and their participation in the Indonesian labor market is presented in Table 4. Table 4 shows clearly that the higher the per capita expenditure, the higher the percentage of married women that become labor force. Percentage of married women whose husbands were informal workers and became labor force was always higher than that did not become labor force in all categories 
of per capita expenditure. However, at the lower per capita expenditure, 1 million rupiahs or lower, the percentage of married women joining the labor force is higher if their husbands are informal workers than women with husbands who are formal workers.

Table 4. Married Women's per Capita Expenditure, Husbands' Occupation, and Participation in Labor Market

\begin{tabular}{|c|c|c|c|c|}
\hline \multirow{2}{*}{$\begin{array}{l}\text { Monthly } \\
\text { Per Capita } \\
\text { Expenditure } \\
\text { (Rp) }\end{array}$} & \multicolumn{2}{|c|}{$\begin{array}{l}\text { Husband is } \\
\text { Formal Worker- }\end{array}$} & \multicolumn{2}{|c|}{$\begin{array}{l}\text { Husband } \\
\text { is Informal } \\
\text { Worker- }\end{array}$} \\
\hline & $\begin{array}{l}\text { Labor } \\
\text { Force } \\
\text { (\%) }\end{array}$ & $\begin{array}{l}\text { Non } \\
\text { Labor } \\
\text { Force } \\
(\%) \\
\end{array}$ & $\begin{array}{l}\text { Labor } \\
\text { Force } \\
(\%)\end{array}$ & $\begin{array}{l}\text { Non } \\
\text { Labor } \\
\text { Force } \\
(\%) \\
\end{array}$ \\
\hline (1) & (2) & (3) & (4) & (5) \\
\hline$<150,000$ & 0.29 & 0.71 & 0.56 & 0.44 \\
\hline $\begin{array}{l}150,000- \\
199,999\end{array}$ & 0.32 & 0.68 & 0.56 & 0.44 \\
\hline $\begin{array}{l}200,000- \\
299,999\end{array}$ & 0.40 & 0.60 & 0.57 & 0.43 \\
\hline $\begin{array}{l}300,000- \\
499,999\end{array}$ & 0.42 & 0.58 & 0.58 & 0.42 \\
\hline $\begin{array}{l}500,000- \\
749,999\end{array}$ & 0.45 & 0.55 & 0.58 & 0.42 \\
\hline $\begin{array}{l}750,000- \\
999,999\end{array}$ & 0.48 & 0.52 & 0.60 & 0.40 \\
\hline $\begin{array}{l}1,000,000- \\
1,499,999\end{array}$ & 0.53 & 0.47 & 0.61 & 0.39 \\
\hline$\geq 1,500,000$ & 0.61 & 0.39 & 0.64 & 0.36 \\
\hline
\end{tabular}

Source: Authors' calculation from data are used in the regression analysis

\section{Effects of Husband's Occupation and Education on the Participation of Married Women in Labor Market}

The estimation model results by applying the probit model to the sample are indicated in Table 5. The sample consists of 237,881 women aged 15 -year-old and above, married, and living with her husband. Table 5 conveys that the likelihood ratio (LR) probability value is 0.000 , smaller than the significance level of alpha 0.05 . Therefore, all independent variables simultaneously and significantly affected married women's labor participation. The $\mathrm{R}^{2}$ value of 0.599 implies that the model may predict the decision of married women in labor market correctly by the total accuracy percentage of $59,99 \%$. Despite that, the figure is just slightly over $50 \%$. Gujarati \& Porter (2009) emphasized that in the probit model, the $\mathrm{R}^{2}$ value is not the major indicator of goodness of fit. It is also in line with the research performed by Hafeez \& Ahmad (2002). The small $\mathrm{R}^{2}$ value was considered normal in research using cross-section data, especially when the number of observations was small. Results of Wald test for each independent variable in Table 5 show that all of the independent variables, that include husbands' occupation, education, age, residence, and the number of children under five-year-old, are significant in influencing the decision of married women participating in labor market at $5 \%$ significant level.

The probit regression coefficient cannot be interpreted directly; thus the marginal effects are used to interpret the effects of independent variables on the dependent variable. The marginal effects are presented in the third column of Table 5. Husband's education has a negative and significant effect on the married women's decision to participate in labor market at the significance level of $5 \%$, and the marginal effect value of 0.0007. It implies that the higher the husband's education, the lower the probability of a married woman participating in the labor market. An additional year of husband's education would decrease the probability of a married woman joining the labor market by $0.07 \%$. The negative relationship is in line with the research findings by Duncan et al. (1993), Unni (1994), Karaoglan \& Okten (2012), İlkkaracan (2012), Rantau \& Zain (2013), and Klasen \& Pieters (2015).

Table 5. Results of Probit Model Estimation

\begin{tabular}{llll} 
Variable & Coefficient & $\begin{array}{l}\text { Marginal } \\
\text { Effect }\end{array}$ & $\mathbf{P}>|\mathbf{z}|$ \\
\hline$(1)$ & $(2)$ & $(3)$ & $(4)$ \\
\hline $\begin{array}{l}\text { husband_ } \\
\text { school }\end{array}$ & -0.0019 & -0.0007 & $0.027^{* *}$ \\
$\begin{array}{l}\text { informal_ } \\
\text { husband }\end{array}$ & 0.2321 & 0.0884 & $0.000^{* * *}$ \\
school & 0.0315 & 0.0120 & $0.000^{* * *}$ \\
Age & 0.0825 & 0.0314 & $0.000^{* * *}$ \\
age ${ }^{2}$ & -0.0009 & -0.0003 & $0.000^{* * *}$ \\
urban & -0.1538 & -0.0586 & $0.000^{* * *}$ \\
Child & -0.1774 & -0.0675 & $0.000^{* * *}$ \\
constant & -1.9097 & & $0.000^{* * *}$ \\
\hline
\end{tabular}




\begin{tabular}{llll}
\hline Variable & Coefficient & $\begin{array}{l}\text { Marginal } \\
\text { Effect }\end{array}$ & $\mathbf{P}>|\mathbf{z}|$ \\
\hline$(1)$ & $(2)$ & $(3)$ & $(4)$ \\
\hline LR chi2 (7) & 10405.02 & $\begin{array}{l}\text { Log } \\
\text { Likelihood }\end{array}$ & -157986.72 \\
Prob>chi2 & 0.0000 & $\begin{array}{l}\text { Number of } \\
\text { Observation }\end{array}$ & 237,881 \\
Count R $R^{2}$ & 0.5999 & & \\
\hline
\end{tabular}

Source: Regression results

Note:

Dependent variable: labor participation $(1=$ labor force; 0

$=$ non labor force)

*** significant at alpha 0.01

** significant at alpha 0.05 .

Simanjuntak (1998) argued that one more school year would add individual working skill and income; thus, husbands' higher education would increase their chance to gain an occupation with a high salary. Hafeez \& Ahmad (2002) found that husbands with high education might make them earn a higher income and encourages husbands to allow their wife to work. When husbands' income is high enough, they might ask their wife to be responsible only for household activities, especially in bringing up their children. Ehrenberg \& Smith (2017) referred to such activities as household production. In addition to that, husbands' higher education indirectly increases their family income in general, influencing their wife's non-labor income. The later increased income will increase demand for leisure as well. In other words, when husbands' income increased due to their higher education, ceteris paribus, the intention of married women to work would decrease.

Husbands' occupation has a positive and significant effect on the decision of married women to participate in labor market at the significance level of $1 \%$. The marginal effect of 0.0884 indicates that married women whose husbands are an informal worker had a higher probability of participating in labor market by $8.84 \%$ than those whose husbands are formal workers.

The findings are in line with the study of Khan \& Khan (2009). They found that women's participation in the labor force was usually determined by the household's financial vulnerability that greatly depended on their husbands' occupational status. Husbands with informal worker status were vulnerable since they often worked without any written contract (Bertulfo, 2011). The absent contract put the household financial condition in uncertain condition, influencing the decision of married women to work (Durand, 1946). Additionally, most informal workers earned less (Bertulfo, 2011) so that it increases the chance of married women to work (Long \& Jones, 1980; Del Boca et al., 2000; Anderson \& Dimon, 1998; Klasen $\&$ Pieters, 2015).

That husband's occupational status as an informal worker increases the chance of married woman to participate in the labor market following the negative effect of husbands' education. Husbands' occupation depends on their education level. Unlike the informal sector, the formal sectors require a certain education level (Harahap $\&$ Sri Hastuty (2006) in Muzakir (2010)). Informal sectors would become an alternative for labor with no education or education that was not up to the standard required by formal sectors.

Apart from husband's occupational status and education, the individual characteristics of married women also have a significant effect on the participation of married women in the labor market. Unlike the husband's education, the education of married women positively affects their participation in the labor market. This is in accordance with previous research conducted by Unni (1994), Hafeez \& Ahmad (2002), Karaoglan $\&$ Okten (2012). The variables of age and age squared also have a significant effect, indicate that the relationship between the age of currently married women and the participation of married women in the labor market is not linear. This nonlinear relationship was also found in Karaoglan \& Okten (2012) study. Initially, the age of married women has a positive effect up to 47 years, but then the age of married women will reduce their chances to become the workforce.

Another factor that has a significant effect on the participation of married women in the labor market is the place of residence. Married women who live in urban areas are less likely 
to participate in the labor market than married women who live in rural areas. In accordance with Anggraeni's research (2015) in Melati (2018), the availability of types of work in villages that are more flexible in terms of working hours encourages women in rural areas to be more economically active compared to women in urban areas. The existence of children under five-year-old is also significant in decreasing the probability of participation of married women in the labor market. These results are consistent with previous research conducted by Maloney (1987), Ribar (1992), and İlkkaracan (2012). Based on Table 5, one more child under fiveyear-old will reduce the opportunity for married women to participate in the labor market by $6.75 \%$.

\section{CONCLUSION AND RECOMMENDATION}

The percentage of women actively participating in the labor market was relatively small, only around $50 \%$, while the participation rate for men was more than $80 \%$. Meanwhile, more than half of $60 \%$ of women ten years of age or older are married. The husband becomes one of the factors affecting women or wife participation in labor market. In the Indonesian perspective, as the household head, the husband is given authorities to decide for family. One of the reasons for the disparity between men and women's participation is the need for married women to obtain their husband's permission when they want to work. The study examines the employment conditions of married women and the effects of husband's occupation and education on their participation in labor market.

The study arrives at several results. Husbands' education negatively influenced the participation of married women in labor market, the opportunity of married women to participate in labor market decreases as husbands' higher education would increase household income. Husbands' occupation, in this case, as an informal worker positively influenced the participation of women in labor market. Married women whose husbands were informal workers had a higher chance of participating in the labor market than those whose husbands were formal workers. This study sheds light on the role of husband's type of occupation on married women's probability of participating in the labor force. Research that focuses on this area of interest was limited in Indonesia.

Following the findings and discussions, several research implications for policies may be recommended. In a household where the husband is an informal worker, the wife tends to participate in the labor force. It might show the vulnerability of the household as the wife should also work to support the husband. The government might identify these households and support them with social security programs if such programs did not cover them. Working condition and wages in the informal sector are less favorable in general; therefore, formal working opportunities should be increased to absorbs more workers and relieve the informal sector.

\section{REFERENCES}

Addabbo, T. (2000). Poverty Dynamics: Analysis of Household Incomes in Italy. Labour, 14(1), 119-144. https://doi.org/10.1111/14679914.00127

Anderson, J. B., \& Dimon, D. (1998). Married Women's Labor Force Participation in Developing Countries: A Case Study of Mexico. Estudios Económicos, 13(1), 3-34.

Becker, G. S. (1965). A Theory of the Allocation of Time. The Economic Journal, 493-517.

Bertulfo, L. (2011). Women and Informal Economy. Office of Development Effectiveness, AusAID. https://dfat.gov.au/aid/how-wemeasure-performance/ode/Documents/ women-informal-economy-lota-bertulfo.pdf

Bibi, A., \& Afzal, A. (2012). Determinants of Married Women Labor Force Participation in Wah Cantt: A Descriptive Analysis. Academic Research International, 2(1), 599-622.

Borjas, G. J. (2013). Labor Economics (6th ed.). McGraw-Hill.

BPS. (2017). Pedoman Pencacah Sakernas 2017. Badan Pusat Statistik.

Bredtmann, J., Otten, S., \& Rulff, C. (2018). Husband's Unemployment and Wife's Labor Supply: The Added Worker Effect Across Europe. ILR Review, 71(5), 1201-1231. 
Del Boca, D., Locatelli, M., \& Pasqua, S. (2000). Employment Decisions of Married Women: Evidence and Explanations. Labour, 14(1), 35-52.

Duncan, K. C., Prus, M. J., \& Sandy, J. G. (1993). Marital Status, Children and Women's Labor Market Choices. The Journal of Socio-Economics, 22(3), 277-288.

Durand, J. D. (1946). Married Women in the Labor Force. American Journal of Sociology, 52(3), 217-223.

Eckstein, Z., \& Lifshitz, O. (2015). Household Interaction and the Labor Supply of Married Women. International Economic Review, 56(2), 427-455.

Ehrenberg, R. G., \& Smith, R. S. (2012). Modern Labor Economics: Theory and Public Policy. Pearson.

Engle, D. C. (1985). Factors Constraining Labor Force Participation of Rural Oklahoma Women. Oklahoma State University.

Frey, B. S., \& Schneider, F. (2000). Informal and Underground Economy. Economic Working Paper, 2000-4.

Gujarati, D. N., \& Porter, D. (2009). Basic Econometrics. Mc Graw-Hill International Edition.

Hafeez, A., \& Ahmad, E. (2002). Factors Determining the Labour Force Participation Decision of Educated Married Women in a District of Punjab. Pakistan Economic and Social Review, XL(1), 75-88.

Hart, K. (1973). Informal Income Opportunities and Urban Employment in Ghana. The Journal of Modern African Studies, 11(1), 61-89.

İlkkaracan, İ. (2012). Why so Few Women in the Labor Market in Turkey? Feminist Economics, 18(1), 1-37. https://doi.org/10 $.1080 / 13545701.2011 .649358$

ILO. (2002). Decent Work and the Informal Economy. International Labour Conference, 90th Session, Item VI.

Karaoglan, D., \& Okten, C. (2012). Labor Force Participation of Married Women in Turkey:
Is There an Added or a Discouraged Worker Effect? IZA Discussion Paper.

Khan, T., \& Khan, R. E. A. (2009). Urban Informal Sector: How Much Women are Struggling for Family Survival. The Pakistan Development Review, 48(1), 67-95.

Klasen, S., \& Pieters, J. (2013). What Explains the Stagnation of Female Labor Force Participation in Urban India? IZA Discussion Paper.

Long, J. E., \& Jones, E. B. (1980). Labor Force Entry and Exit by Married Women: A Longitudinal Analysis. The Review of Economics and Statistics, 62(1), 1-6.

Maloney, T. (1987). Employment Constraints and the Labor Supply of Married Women: A Reexamination of the Added Worker Effect. The Journal of Human Resources, 22(1), 51-61. https://doi.org/10.2307/145866

Mano, Y., \& Yamamura, E. (2011). Effects of Husband's Education and Family Structure on Labor Force Participation and Married Japanese Women's Earnings. Japanese Economy, 38(3), 71-91. https://doi. org/10.2753/jes1097-203x380303

Melati, F. (2018). Paritas dan Partisipasi Angkatan Kerja Perempuan Kawin Indonesia: 1979 2017. Universitas Indonesia.

Muzakir, M. (2010). Kajian Persepsi Harapan Sektor Informal Terhadap Kebijakan Pemberdayaanusaha Pemerintah Daerah Kabupaten Tojo Unauna. Media Litbang Sulteng, 3(1), 12-20.

Noerdin, E., Agustini, E., Pakasi, D. T., Aripurnama, S., \& Hodijah, S. N. (2006). Potret Kemiskinan Perempuan. Women Research Institute.

Pitoyo, A. J. (2007). Dinamika Sektor Informal di Indonesia: Prospek, Perkembangan, dan Kedudukannya dalam Sistem Ekonomi Makro. Populasi, 18(2).

Rantau, D. C. M., \& Zain, I. (2013). Analisis Regresi Double Hurdle terhadap FaktorFaktor yang Mempengaruhi Partisipasi Perempuan Kawin dalam Kegiatan Ekonomi di Jawa Timur. Jurnal Sains Dan Seni ITS, 2(2), D129-D134. 
Ribar, D. C. (1992). Child Care and the Labor Supply of Married Women: Reduced Form Evidence. The Journal of Human Resources, 27(1), 134-165. https://doi. $\operatorname{org} / 10.2307 / 145915$

Sasaki, M. (2002). The Causal Effect of Family Structure on Labor Force Participation among Japanese Married Women. The Journal of Human Resources, 37(2), 429-440.

Simanjuntak, P. J. (1998). Pengantar Ekonomi Sumber Daya Manusia (2nd ed.). FE UI.

Suhapti, R. (1995). Gender dan Permasalahannya. Buletin Psikologi, 3(1), 44-50.
Todaro, M. P., \& Smith, S. C. (2012). Economic Development (11th ed.). Pearson.

Tzannatos, Z. (1999). Women and Labor Market Changes in the Global Economy: Growth Helps, Inequalities Hurt and Public Policy Matters. World Development, 27(3), 551-569.

Unni, J. (1994). Labour Participation Decisions of Married Women in Rural India. Indian Economic Review, 29(2), 177-193.

Yustika, A. E. (2000). Industrialisasi Pinggiran. Pustaka Pelajar. 
